University of Nebraska - Lincoln

DigitalCommons@University of Nebraska - Lincoln

Congreso internacional sobre iconografía

precolombina, Barcelona 2019. Actas.

8-20-2020

\title{
The Ramey Incised Pottery of Cahokia (IL) USA: Diffusion and Reinterpretation of its Iconographic Message
}

Melissa Mattioli

Follow this and additional works at: https://digitalcommons.unl.edu/actas2019

Part of the American Material Culture Commons, Indigenous Studies Commons, Museum Studies Commons, Other History of Art, Architecture, and Archaeology Commons, and the Other Languages, Societies, and Cultures Commons

This Article is brought to you for free and open access by the Zea E-Books at DigitalCommons@University of Nebraska - Lincoln. It has been accepted for inclusion in Congreso internacional sobre iconografía precolombina, Barcelona 2019. Actas. by an authorized administrator of DigitalCommons@University of Nebraska - Lincoln. 


\title{
The Ramey Incised Pottery of Cahokia (IL) USA: Diffusion and Reinterpretation of its Iconographic Message
}

\author{
Melissa Mattioli \\ Universitat Autonoma de Barcelona; melissamattioli9@gmail.com
}

\begin{abstract}
Resumen
Una interpretación iconográfica adaptada y adoptada por toda la zona Mississippiana. Cahokia es el asentamiento más antiguo y más grande en la América del Norte precolombina. Situado a pocos kilómetros de la actual ciudad de St. Louis, MO (USA), este sitio arqueológico se convirtió en el mayor asentamiento Mississippiano desde la mitad del siglo XI hasta su abandono, al final del siglo XIV. El modelo cosmológico Mississippiano, trasmitido a través de la iconografía de la cerámica Ramey Incised, generalmente está relacionado con los mundos superior e inferior. Tradicionalmente, se reconoce que la presencia de la cosmógrafia de estilo Cahokiano fuera del American Bottom representa un deseo local de participar en el fenómeno cultural cahokiano. Sin embargo, muchos expertos están de acuerdo en que los habitantes periféricos no adoptaron pasivamente las prácticas de políticas más poderosas sino que, de alguna manera, las reinterpretaron basándose en conocimientos, entendimientos e historias locales.
\end{abstract}

Palabras clave: Cahokia, Mississippian, Ramey Incised, Cerámica, Iconografía

\begin{abstract}
An iconographic interpretation adapted and adopted across the Mississippian area. Cahokia is the earliest and largest settlement of pre-Columbian North America. Located in the American Bottom floodplain, a few kilometers from present day St. Louis, MO (USA), this archaeological site had risen to be the greatest Mississippian settlement by the middle of the 11th century until its abandonment at the end of the 14th century. The Mississippian cosmological model transmitted through Ramey Incised pottery iconography is generally related to upper and lower worlds. Traditionally, it is granted that the presence of Cahokia-style cosmograms outside of the American Bottom
\end{abstract}

represents a local desire to participate in the Cahokian cultural phenomenon. However, many experts agree that peripheral inhabitants did not passively adopt the practices of more powerful core polities but, in some ways, they reinterpreted them based on local knowledge, understandings and histories.

Keywords: Cahokia, Mississippian, Ramey Incised, Pottery, Iconography

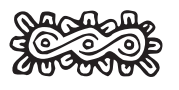

\section{Cahokia, The Largest Settlement of Pre-Columbian North America}

The Mississippian centre, known as Cahokia, is located in the American Bottom floodplain, at the confluence of the Missouri and Mississippi River, near the modern city of St. Louis, in south western Illinois, USA. The archaeological site expands over an area of 13sq km including 120 mounds. Cahokia was built following a plan based on the cardinal directions, adopting Monks Mound as the centre of the scheme (Dalan et al., 2003; Emerson, 1997; Fowler, 1997; Young and Fowler, 2000; Iseminger, 2010; Kelly and Brown, 2014; Milner, 2006; Pauketat and Emerson, 1997; Pauketat, 2004, 2009; Pauketat and Alt, 2015). This archaeological site had risen to be the greatest Mississippian settlement by the middle of the 11 th century until its final abandonment marked by the arrival of French colonists in the 18th century and coincided with the general depopulation of a wider region later known as the Vacant Quarter (Kelly, 2009). 


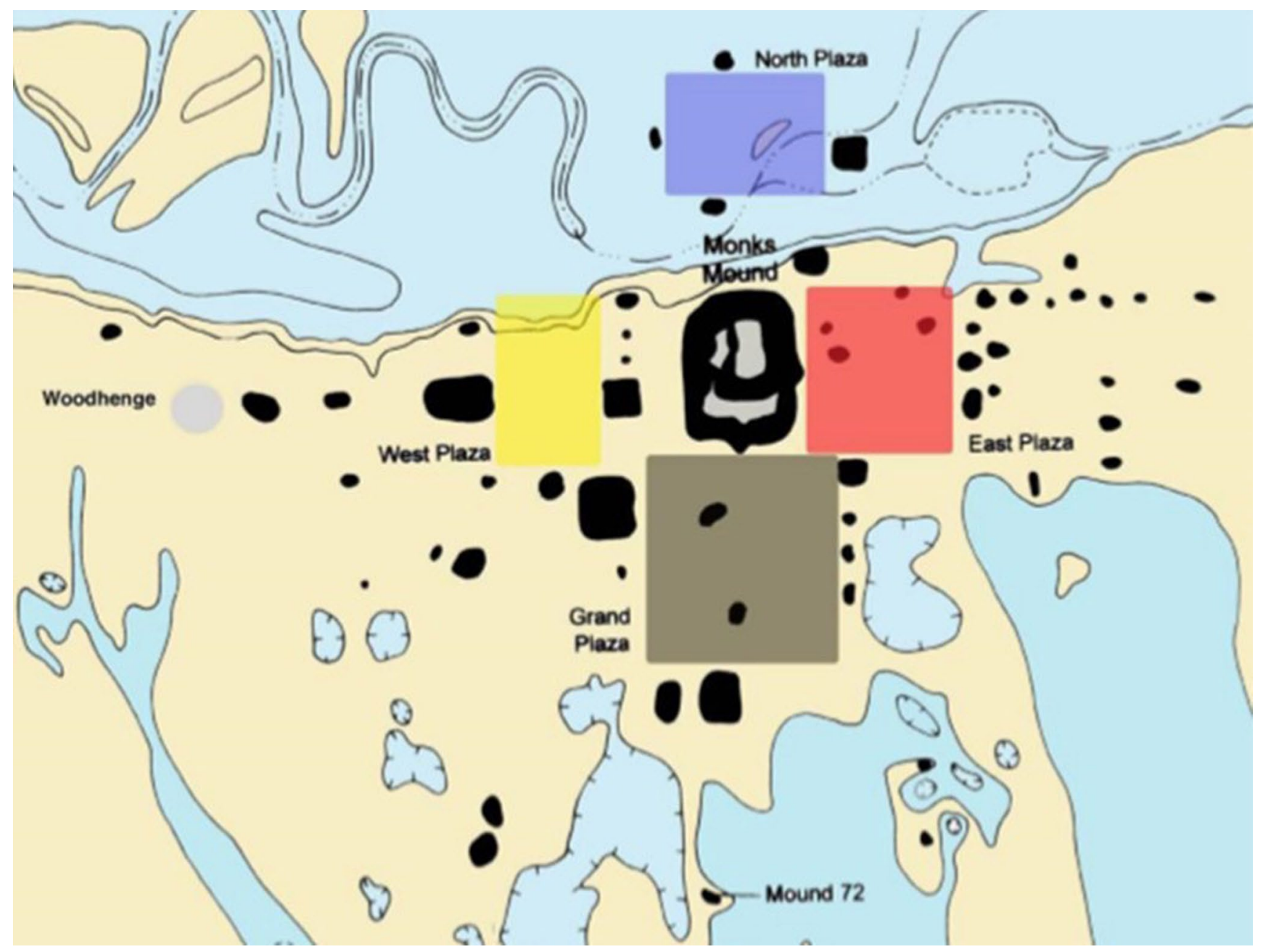

Map 1- Monks Mound surrounded by the four Plazas, Courtesy of J. E. Kelly.

The Mississippian Culture and The Mississippian Period

The Mississippian period was introduced by two older occupational phases in the Mississippian floodplains: the Woodland period (AD 600 - 750) and the Emergent Mississippian period (AD 750 - 1050). These two phases are significant because of the increasing concentration of inhabitants and the intensification of agriculture, the construction of hunting tools, the emergence of a ranked society, communities and religious events (Dalan et al., 2003; Kelly, 1982,1990a, 1990b). But it is in the Mississippian period (AD 1050 - 1400) that Cahokia began to expand (Kelly and Brown, 2014). The Mississippian culture is defined on the basis of a set of cultural tracts: the construction of earthworks, cultivation of maize, wall trenched structures, shell tempered pottery, lithic technology, the development and diffusion of a system of religious beliefs known as South-Eastern Ceremonial Complex (Brown and Kelly, 2000). During the Cahokia Big Bang (Pauketat, 1994), the village become a real urban centre with complex social classes and hierarchies, but few decades later, at the end of the Moorehead phase (AD 1200 - 1275), Cahokia began to collapse and eventually was abandoned (Kelly, 2009). As long as Cahokia was declining, other powerful centres arose in the wider Mississippian world: Moundville, ${ }^{1}$ AL; Spiro, ${ }^{2} \mathrm{OK}$ and Ethowa, ${ }^{3} \mathrm{GA}$ linked by a strong presence of Cahokia artefacts and beliefs which spread across the Mississippian valley creating a cultural sphere called Pax Cahokiana (Pauketat and Alt, 2015).

1 On the Moundville Site, see Knight and Steponaitis (1998).

2 On the Spiro Site, see Brown (1996).

3 On the Ethowa Site, see King (2003). 


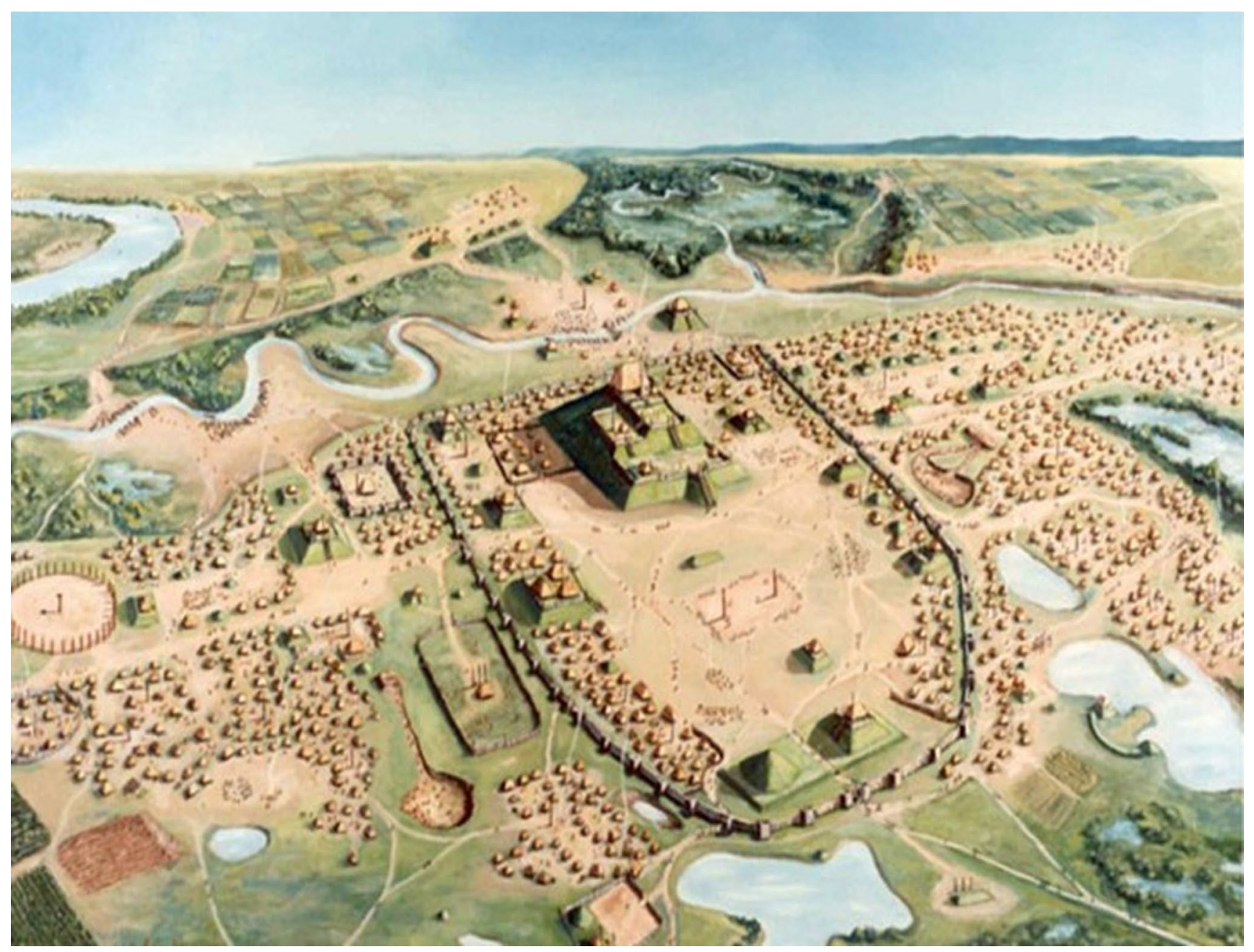

Fig. 1- Aerial Reconstruction of Monks Mound and Downtown Cahokia, Courtesy of Cahokia Mounds Historic Site.

\section{The First Italian Archaeological Mission at Cahokia Site, Purposes and Results}

In 2011, the University of Bologna, IT, thanks to the collaboration with the Washington University in Saint Louis, MO, USA, started a new archaeological project called Maicah. ${ }^{4}$ Located in the West Plaza of Cahokia site, the Italian excavation area was attached to the older $15 \mathrm{~B}$ tract grid. In fact, during the 60s, due to an intense highway construction campaign, in the American Bottom area was established an Archaeological Salvage program (Wittry and Vogel, 1962; Kelly, 1980, 1996b). Fifty years later, the Italian campaign attached his grid to it as to extend the survey to the west side of the highway (Mattioli, 2017; Valese, 2017).
The Maicah project yielded evidences of Emergent Mississippian and Mississippian residential areas and, in the latest occupational phases, of a circular and a rectangular bastioned compound. These compounds suggest a socio-political use of the plaza, brought back to a residential use at the end of the Moorehead phase, testified also by a variety of findings discovered: hammerstones, arrowhaeads, worked bones, copper beads and pottery (Mattioli, 2017, Valese, 2017). Considering all the ceramic findings unearthed during a six years excavation project, we focused our attention on the Ramey Incised pottery variety, developing a research regarding an Iconographic analysis comparing pottery sherds discovered during the Italian excavation, which is the classic Ramey Incised style example, to those detected across Cahokians hinterland's sites. 

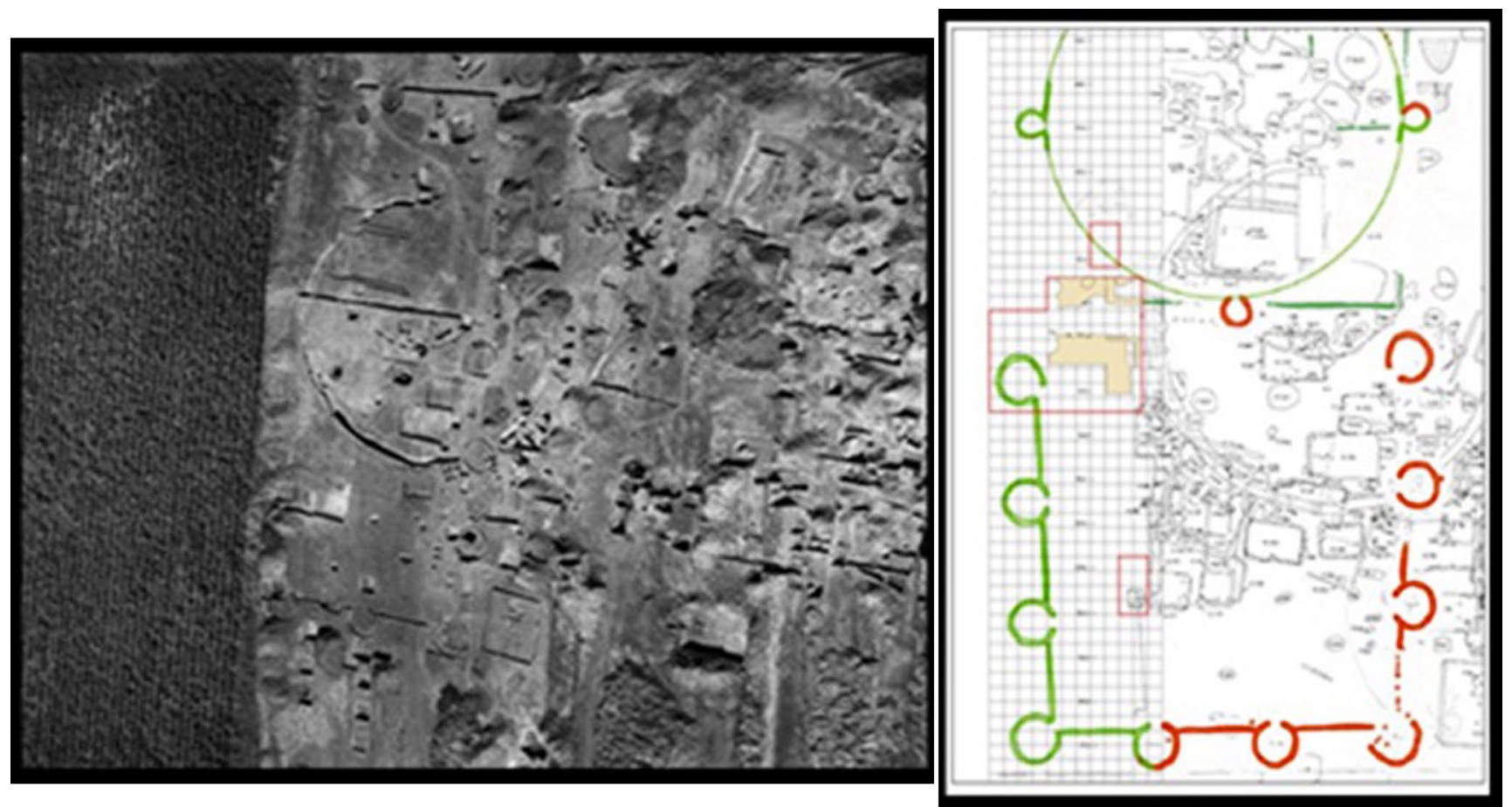

Fig. 2 - On the left: A General Shot of 15B Tract, Cahokia (1970 ca), Research and Collection Centre, Springfield (IL). On the right: GIS Reconstruction of Compound A and B/C,15B Tract, Cahokia (Valese, 2017)

\section{Introducing Ramey Incised Pottery Style and Iconography}

Ramey Incised jars were cosmograms through which Cahokians attempted to frame the relationships between different social groups and the broader cosmos. During the Stirling phase (AD 1100 - 1200), in the middle of the Mississippian period, Ramey Incised pots were mostly popular in Cahokia. These jars were dark slipped and shell tempered with sharp angled shoulders, generally rounded lips and incised motifs of political and religious significance (Emerson, 1989; Emerson, 1997a; Griffin, 1949; Griffith, 1981; Pauketat, 1997; Pauketat and Emerson, 1991). The Mississippian cosmological model, in general, includes the upper and lower worlds represented around a central axis, or axis mundi (Emerson, 1989; Lankford, 2004, 2007; Pauketat, 2004; Pauketat and Emerson 1991). This model also embodies a quadripartite community organization world view, as seen in villages built according to the cardinal directions, with mounds or houses surrounding a plaza with a central pole (Kelly, 1996a; Kelly and Brown, 2014). These pots were widely distributed and are commonly found in both ceremonial and domestic contexts, highlighting their value in Mississippian communities (Emerson and Pauketat, 2008; Griffith, 1981; Pauketat and Emerson, 1991).
Hall suggested that Ramey motifs generally relate to water, rainbows, and bird symbolism (Hall, 1991). Griffith further suggests that Ramey Incised motifs reference the sun and moon in addition to possible anthropomorphic representation (Griffith, 1981). Later, Emerson separated group motifs by theme (Emerson, 1989, 1997b). We can recognize 14 categories of Ramey Incised design elements: 9 basic categories elements, 3 categories of basic elements combinations and 2 categories of lines (Emerson, 1997b; Emerson, 1989; Richards, 1992). The use of a Ramey Incised pot was a meaningful experience: the pot embodied the cosmos, so that in holding a Ramey Incised vessel, devotees possessed the cosmos in their hands.

\section{Ramey Incised Pottery. Geographic Distribution and the Diffusion of its Political and Religious Influence}

Ramey Incised pots, as other artifacts, had a huge geographic distribution. Mostly during the latest phases of the Mississippian period all the civilizations touched by the Mississippi river shared these vessels. We can assume that these interactions were based on political and economic aspects (Milner, 1998; Muller, 1997), but it is clear that many of these contacts had strong religious 

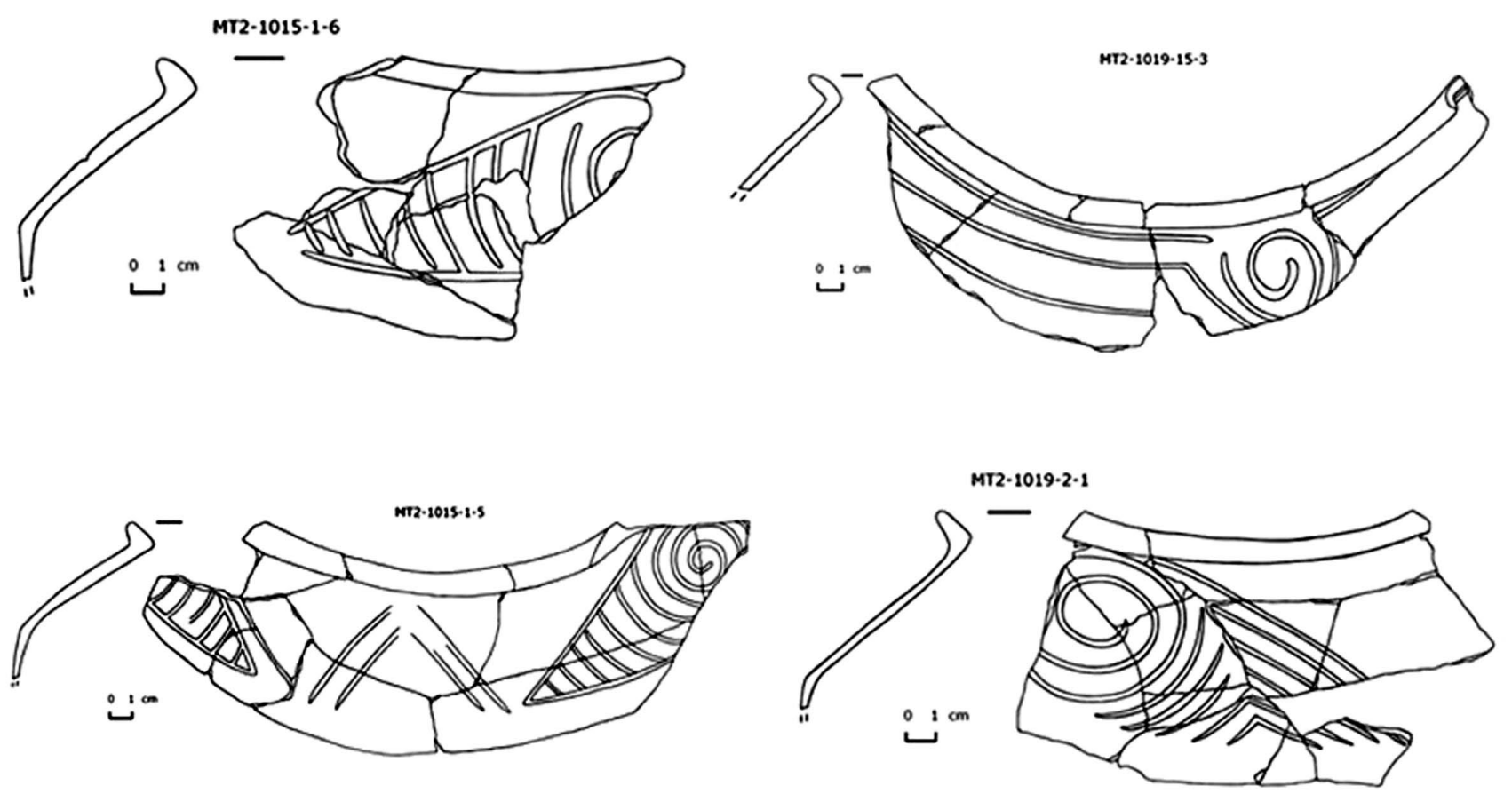

Fig. 3 - Ramey Incised Pottery Rim sherds detected from Merrell Tract II Italian excavation, drawings (M. Mattioli).

characteristics and implications (Brown and Kelly, 2000; Conrad, 1991; Emerson, 1989; Emerson, 1991a; Emerson and Lewis, 1991; Fowler et al., 1999; Hall, 1991; Kelly, 1991; Knight et al., 2001; Pauketat, 1997; Pauketat, 2004; Wilson, 2011). Thanks to the pottery analysis and to the goods distribution study in general, we know that different and therefore distant communities were in contact. But how did they react to this contact, what was the spiritualistic and the materialistic expression consequence to this interaction? Did hinterland Mississippian people buy into a Cahokian understanding of the cosmos wholesale, or did they reinterpret it based on local understanding and histories? We started by examining variation in Ramey Incised iconography motifs and design fields from Cahokia's northern hinterland sites. This data is statistically compared with Emerson's typology taken from the American Bottom Ramey Incised analysis (Emerson, 1989). In an era of increasing social complexities, Cahokians relied on religious ceremonies and ritual objects to frame relationships among different social groups and the supernatural forces comprising the broader cosmos (Alt and Pauketat, 2007; Emerson et al., 2008; Emerson and Pauketat, 2008; Pauketat, 1997; Pauketat, 2002; Pauketat, 2003; Pauketat, 2010; Pauketat, 2013; Wilson, 1996). Early theories of cultural contact suggest that inhabitants of peripheral settlements unquestioningly adopted the practices of a core polity. In reality, as we aim to demonstrate, they may resist dominant influence or negotiate it on their own terms and in reference to their own histories and existing worldviews (Dietler, 2010; Lightfoot and Martinez, 1995; Pauketat and Alt, 2005; Silliman, 2005; Stein, 2002).

\section{Ramey Incised Style, An Iconographic Comparison between Cahokia and Northern Hinterland Sites Pottery}

The presence of Cahokia style cosmograms outside of the American Bottom surely represents a local desire to participate in the Cahokian cultural phenomenon, although there is a relevant interregional variation in the way Cahokian religious concept was localized and practiced. The Northern communities are usually considered as belonging to the Woodland culture prior to contact with Cahokia, and there are also significant variations among different regional traditions. Inhabitants of these hinterland settlements maintained many earlier local style traditions, although motifs and organizational scheme influence the way Ramey Incised jars were decorated in these regions. It seems that Mississippian pottery in Cahokia's northern hinterland exhibits patterns of Woodland-Mississippian hybridity (Bardolph, 2014; Delaney-Rivera, 2000; 


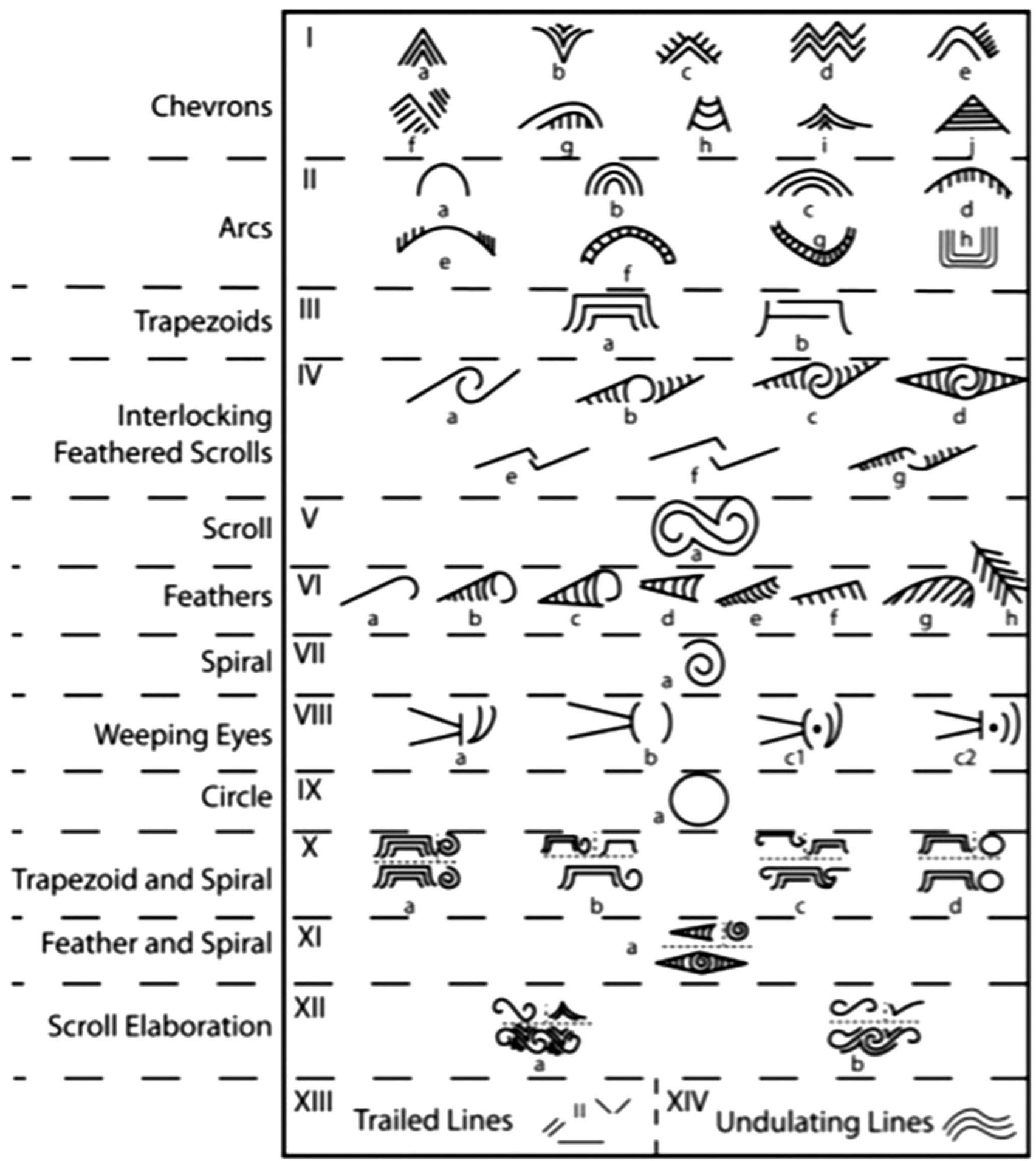

Fig. 4 - 14 Categories of Iconographic Elements of Ramey Incised Pottery (Emerson, 1997b; Emerson, 1989; Richards, 1992).

Delaney-Rivera, 2004; Emerson, 1991b; Finney, 1993; Millhouse, 2012; Richards, 1992; Wilson, 2015; Wilson et al., 2017; Zych, 2013). Most of the Ramey Incised jars found north of Cahokia appear to be manufactured locally, with a minority of samples being Cahokian imports (Hall, 1991; Harn, 1991; Pauketat and Emerson, 1991; Stoltman, 1991). Northern Cahokia pots frequently feature handles, lip notching and are sometimes even cord 
marked below the shoulder (Delaney-Rivera, 2000; Emerson, 1991b; Esarey, 2000). Some hinterland potters were highly skilled in the production of fine Cahokia pottery; however, iconographic analysis reveal many northern hinterland Ramey Incised pots are statistically different from those found in the greater Cahokia area (Conrad, 1991; Delaney-Rivera, 2000; Emerson, 1991a; Mollerud, 2005). As an example, Aztalan ${ }^{5}$ patterns seem to have drawn on chevron motifs significantly more than any other motif class. In fact Aztalan's most common motif is the barred triangle, a version of the chevron class of motifs that is extremely rare in the American Bottom. This means that the motif was borrowed from earlier woodland iconographic traditions. This suggests that Aztalan's most common motif was not a Cahokian import, but most likely represents a continuity of certain Woodland traditions at Aztalan that locals were already accustomed to use (Friberg, 2017). There are also some fundamental deviations from the dominant quadripartite organizational layout thought to hold religious significance for Cahokians, e.g. Ramey Incised vessels from CIRV $^{6}$ and LIRV ${ }^{7}$ have a tripartite layout consisting of six motifs, rather than the typical four or eight found at Cahokia. In addition, Aztalan and Apple River Valley ${ }^{8}$ pots bear mostly continuous design layout in which the entire rim is filled with incising; this might be another example carried through from Woodland traditions. Furthermore at Aztalan, Mississippian motifs like the spiral and circle are often inserted in the blank spaces within these continuous Woodland style design fields, rather than side by side separated by blank areas, which is the most common practice in the American Bottom (Friberg, 2017). In conclusion, after investigating variation in iconographic motifs and design fields on Ramey Incised pots detected across Cahokia northern hinterland sites, we can identify: a different combination of design elements, a tripartite organizational layout and a continuous design layout in which the entire rim is filled with incising.

\section{A Starting Point for Reflections and Conclusions.}

The data collected seems to show that northern hinterland people had a desire to engage in Cahokian religion.
They emulated the cultural practices of a dominant polity, while also trying to safeguard their own local traditions. Local potters produced religiously charged Cahokian style Ramey Incised jars organizing Ramey design fields using local concepts of space, such as tripartite and continuous design layout. The patterns reveal that different communities in the northern Midwest generated distinct local flavors of Mississippian by mixing Woodland and Cahokian religious practices and material culture. Hinterland groups selectively adopted aspects of Mississippian ways of life, but incorporated them and gave them meaning within the local contexts. When we look critically at the production of Ramey Incised jars, certain production steps appear to be Cahokian inspired, while others represent local ways of manufacturing (Friberg, 2017). While the trademark Cahokian iconographic motifs on Ramey Incised jars could have been easily adopted by northern groups, on the other hand, the spatial organization of the design fields on these jars represents a part of the production process which reflects the cultural background of the potters. This is a particularly cogent point as the design layout (quadripartition) used in the Cahokian Ramey Incised prototypes has been demonstrated to have religious significance for American Bottom potters and consumers (Pauketat and Emerson, 1991; Perino, 1971; Friberg, 2017). We cannot be sure whether variation (tripartition) in Ramey Incised design layout represents a conscious choice to perpetuate local cosmological interpretations or simply an incomplete understanding of the importance of quadripartition within a Cahokian cosmological context. Regardless, this variation indicates that these groups did not adopt Mississippian religion wholesale. We can assume stylistic variation between Ramey Incised pottery at Cahokia and in the hinterland regions suggests differences in the perceived composition and structure of the cosmos from region to region and reveals the power of local worldview in the negotiation of Cahokian religious influence. As a starting point, we might conclude that there was an entanglement between Cahokians and northern ideas and symbolism, rather than a wholesale adoption of a Mississippian religious tradition.

5 On the Aztalan Site, see Richards (1992) and Mollerud (2005).

6 On the Central Illinois River Valley Site, see Conrad (1993) and Meinkoth (1993).

7 On the Lower Illinois River Valley Site, see Delaney-Rivera (2000).

8 On the Apple River Valley Site, see Mollerud (2005), Emerson et al. (2007), Finney (1993), and Millhouse (2012). 

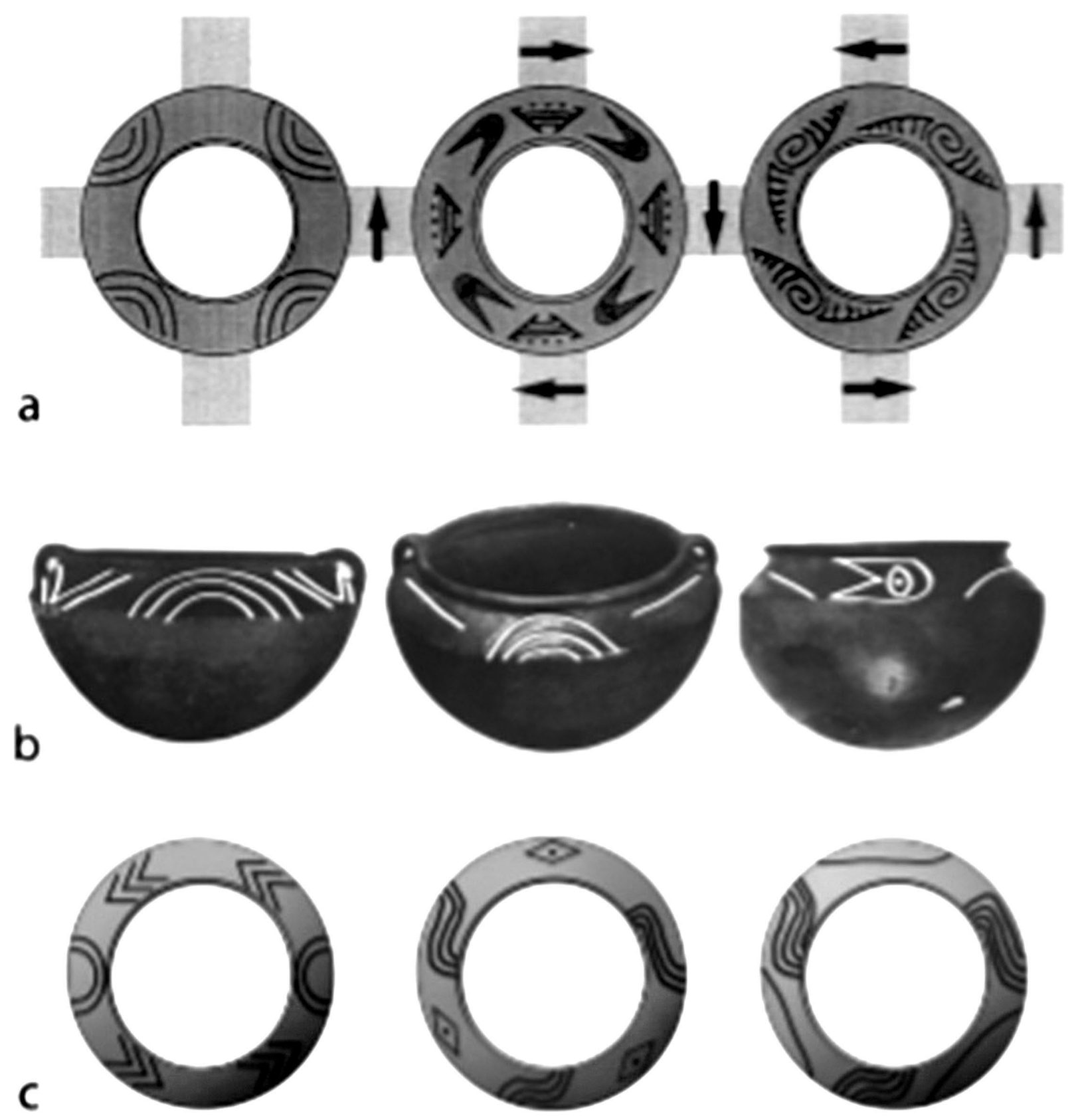

Fig 5-a) American Bottom vessels showing quadripartite design layout (Pauketat and Emerson 1991); b) Tripartite design layouts from the LIRV (adapted from Perino 1971); c) Tripartite design layouts from CIRV, (Friberg, 2017).

\section{References}

ALT, S. M. and PAUKETAT, T. R., 2007. Sex and the Southern Cult. In Southeastern Ceremonial Complex: Chronology, Content, Context. Adam King (Eds.), pp. 232-250. University of Alabama Press, Tuscaloosa.

BARDOLPH, D. N., 2014. Evaluating Cahokian Contact and Mississippian Identity Politics in the Late Prehistoric
Central Illinois River Valley. American Antiquity 79:69-89. BROWN, J. A., 1996. The Spiro Ceremonial Center. The Archaeology of Arkansas Valley Caddoan Culture in Eastern Oklahoma. Memoirs of the Museum of Anthropology University of Michigan, Ann Arbor.

BROWN, J. A. and. Kelly, J. E., 2000. Cahokia and the Southeastern Ceremonial Complex. In Mounds, Modoc, and Mesoamerica: Papers in Honor of Melvin L. Fowler, Steven R. 
Ahler, ed. Pp. 469-510. Illinois State Museum Scientific Papers, Springfield.

CONRAD, L. A. 1991. The Middle Mississippian Cultures of the Central Illinois Valley. In Cahokia and the Hinterlands: Middle Mississippian Cultures of the Midwest. Thomas E. Emerson and R. Barry Lewis eds., pp. 119-156. University of Illinois Press, Urbana.

CONRAD, L. A. 1993. Two Elaborate Middle Mississippian Graves from the Kingston Lake Site, Peoria County, Illinois. In Highways to the Past: Essays on Illinois Archaeology in Honor of Charles J. Bareis, Illinois Archaeology, Vol. 5. Thomas E. Emerson, Andrew C. Fortier, and Dale L. McElrath eds., pp. 297-314. Illinois Archaeological Society, Springfield.

COSTIN, Cathy L. 2005. The Study of Craft Production. In Handbook of Methods in Archaeology, H. Maschner ed., pp 1032-1105. AltaMira Press.

DALAN, R. A., HOLLEY, G. R., WOODS, W. I., WATTERS, H. W. Jr. and KOEPKE J. A. 2003. Envisioning Cahokia: A Landscape Perspective. Northern Illinois University Press, DeKalb.

DELANEY-RIVERA, C. 2000. Mississippian and Late Woodland Cultural Interaction and Regional Dynamics: A View from the Lower Illinois River Valley. PhD dissertation, Department of Anthropology, University of California, Los Angeles.

DELANEY-RIVERA, C. 2004. From Edge to Frontier: Early Mississippian Occupation of the Lower Illinois River Valley. Southeastern Archaeology 23:41-56.

DIETLER, M. 2010. Archaeologies of Colonialism: Consumption, Entanglement and Violence in Ancient Mediterranean France. University of California Press, Berkeley.

EMERSON, T. E. 1989. Water, Serpents, and the Underworld: An Exploration into Cahokia Symbolism. In The Southeastern Ceremonial Complex: Artifacts and Analysis, P. Galloway ed., pp. 45-92. University of Nebraska Press, Lincoln.

EMERSON, T. E. 1991a. Some Perspectives on Cahokia and the Northern Mississippian Expansion. In Cahokia and the Hinterlands: Middle Mississippian Cultures of the Midwest, Thomas E. Emerson and R. Barry Lewis eds., pp. 221236. University of Illinois Press, Urbana

EMERSON, T. E. 1991b. The Apple River Mississippian Culture of Northwestern Illinois. In Cahokia and the Hinterlands: Middle Mississippian Cultures of the Midwest, Thomas E. Emerson and R. Barry Lewis eds., pp. 221-236. University of Illinois Press, Urbana

EMERSON, T. E. 1997a. Elite Ideology and the Mississippian Cosmos. In Cahokia: Domination and Ideology in the Mississippian World, Timothy R. Pauketat and Thomas E. Emerson eds., pp. 190-228. University of Nebraska Press, Lincoln.

EMERSON, T. E. 1997b. Cahokia and the Archaeology of Power. University of Alabama Press, Tuscaloosa.

EMERSON, T. E. and BARRY R. L. (Eds.), 1991. Cahokia and the Hinterlands: Middle Mississippian Cultures of the Midwest.
University of Illinois Press, Urbana.

EMERSON, T. E., MILLHOUSE, P. G. and SCHROEDER, M. B. 2007. The Lundy Site and the Mississippian Presence in the Apple River Valley. Wisconsin Archeologist 88(2):1-123.

EMERSON, T. E., Alt S. M. and PAUKETAT T. R. 2008. Locating American Indian Religion at Cahokia and Beyond. In Religion, Archaeology, and the Material World, Lars Fogelin (Ed.), pp. 216-236. Occasional Paper No. 36. Center for Archaeological Investigations, Southern Illinois University, Carbondale.

ESAREY, D. 2000. Late Woodland Maples Mills and Mossville Phase Sequence in the Central Illinois River Valley. In Late Woodland Tradition and Transformation Across the Midcontinent, Thomas E. Emerson, Dale L. McElrath, and Andrew C. Fortier eds., pp. 387-410. University of Nebraska Press, Lincoln.

FINNEY, F. A. 1993. Cahokia's Northern Hinterland as Viewed from the Fred Edwards Site in Southwest Wisconsin: Intrasite and Regional Evidence for Production, Consumption, and Exchange. PhD dissertation, Department of Anthropology, University of Wisconsin, Madison.

FOWLER, M. L. 1997. The Cahokia Atlas: a historical atlas of Cahokia archaeology. (Revised edition of the 1989 Illinois Historic Preservation Agency edition). University of Illinois Press, Urbana.

FOWLER, M. L., ROSE J., VANDER LEEST B. and AHLER S. A. 1999. The Mound 72 Area: Dedicated and Sacred Space in Early Cahokia. Reports of Investigations No. 54. Illinois State Museum, Springfield.

FRIBERG, C. M., 2017. Cosmic negotiations: Cahokian religion and Ramey Incised pottery in the northern hinterland, Southeastern Archaeology, 37(1):39-57.

GRIFFIN, J. B. 1949. The Cahokia Ceramic Complexes. In Proceedings of the Fifth Plains Conference for Archaeology, J. L. Campe ed., pp. 44-58. University of Nebraska, Lincoln.

GRIFFITH, R. J. 1981. Ramey Incised Pottery, Illinois Archaeological Society, Springfield.

HALL, R. L. 1991. Cahokia Identity and Interaction Models of Cahokia Mississippian. In Cahokia and the Hinterlands: Middle Mississippian Cultures of the Midwest, Thomas E. Emerson and R. Barry Lewis eds., pp. 3-34. University of Illinois Press, Urbana.

HARN, A. D. 1991. The Eveland Site: Inroad to Spoon River Mississippian Society. In New Perspectives on Cahokia: Views from the Periphery, James B. Stoltman ed., pp. 129153. Monographs in World Archaeology No. 2. Prehistory Press, Madison, Wisconsin.

ISEMINGER, W. R. 2010. Cahokia Mounds: America's first City. History Press

KELLY, J. E. 1982. Formative Developments at Cahokia and the Adjacent American Bottom: A Merrell Tract Perspective. 1980 PhD dissertation, University of WisconsinMadison. Published by Archaeological Research laboratory, Western Illinois University, Macomb, 2 volumes. 
KELLY, J. E. 1990a. The Range Site Community Patterns and the Mississippian Emergence. In The Mississippian Emergence, Bruce D. Smith, ed. Pp. 67-112. Smithsonian Institution Press, Washington, DC.

KELLY, J. E. 1990b. The Emergence of Mississippian Culture in the American Bottom Region. In The Mississippian Emergence, Bruce D. Smith, ed. Pp. 113-152. Smithsonian Institution Press, Washington, DC

KELLY, J. E. 1991. The Evidence for Prehistoric Exchange and Its Implications for the Development of Cahokia. In New Perspectives on Cahokia: Views from the Periphery, James B. Stoltman ed., pp. 65-92. Monographs in World Archaeology No. 2. Prehistory Press, Madison, Wisconsin.

KELLY, J. E. 1996a. Redefining Cahokia: Principles and Elements of Community Organization. In The Ancient Skies and Sky Watchers of Cahokia: Woodhenges, Eclipses, and Cahokian Cosmology, Melvin L. Fowler ed. The Wisconsin Archeologist, v. 77, no. 3-4. Wisconsin Archeological Society, Milwaukee.

KELLY, J. E. 1996b. The Public Architecture on the Merrell Tract, Cahokia. Draft report submitted to the Cahokia Mounds Museum Society, Collinsville. Central Mississippi Valley Archaeological Research Institute, Columbia, IL. The Wisconsin Archaeologist 77 (3-4):97-119.

KELLY, J. E. 2009. Contemplating Cahokia's Collapse. In Global Perspectives on the Collapse of Complex Systems. J. A. Rayley, ed. Pp. 147-168, Maxwell Museum of Anthropology Anthropological Papers 8. Albuquerque, NM.

KELLY, J. E. and BROWN, J. A. 2014. Cahokia: The Processes and Principles of the Creation of an Early Mississippian City. In Making Ancient Cities. Space and Place in Early Urban Societies, A. T. Creekmore III, ed. Pp. 292-336. Cambridge University Press.

KING, A. 2003. Etowah. The Political history of a Chiefdom Capital. The University of Alabama Press, Tuscaloosa and London.

KNIGHT, V. J. Jr. and STEPONAITIS, V. 1998. Archaeology of the Moundville Chiefdom. Smithsonian Institution Press, Washington, DC

KNIGHT, V. J. Jr., BROWN, J. A. and LANKFORD G. E. 2001. On the Subject Matter of Southeastern Ceremonial Complex Art. Southeastern Archaeology 20:129-141.

LANKFORD G. E. 2004. World on a String: Some Cosmological Components of the Southeastern Ceremonial Complex. In Hero, Hawk, and Open Hand: American Indian Art of the Ancient Midwest and South, Richard F. Townsend ed., pp. 207-218. The Art Institute of Chicago, Yale University Press, New Haven, Connecticut.

LANKFORD G. E. 2007. The Great Serpent in Eastern North America. In Ancient Objects and Sacred Realms: Interpretations of Mississippian Iconography, F. Kent Reilly, III, and James F. Garber eds., pp. 107-135. University of Texas Press, Austin.

LIGHTFOOT, K. G., and MARTINEZ A. 1995. Frontiers and
Boundaries in Archaeological Perspective. Annual Review of Anthropology 24:471-492.

MATTIOLI, M. 2017. Report of the ceramic materials recovered from the Merrell Tract excavations, Cahokia Site (2011-2016). Unpublished report.

MEINKOTH, M. C. 1993. Middle Mississippian Households in the Central Illinois River Valley: Examples from the Tree Row and Baker-Preston Sites. In Highways to the Past: Essays on Illinois Archaeology in Honor of Charles J. Bareis, Illinois Archaeology, Vol. 5, Thomas E. Emerson, Andrew C. Fortier, and Dale L. McElrath eds., pp. 315-330. Illinois Archaeological Society, Springfield.

MILLHOUSE, P. G. 2012. The John Chapman Site and Creolization on the Northern Frontier of the Mississippian World. PhD dissertation, Department of Anthropology, University of Illinois, Urbana-Champaign.

MILNER, G. R. 1998. The Cahokia Chiefdom: The Archaeology of a Mississippian Society. Smithsonian Institution Press, Washington, DC.

MOLLERUD, K. J. 2005. Messages, Meanings and Motifs: An Analysis of Ramey Incised Ceramics at the Aztalan Site. Master's thesis, Department of Anthropology, University of Wisconsin- Milwaukee, Milwaukee.

MULLER, J. 1997. Mississippian Political Economy. Plenum Press, New York.

PAUKETAT, T. R. 1994. The ascent of chiefs: Cahokia and Mississippian politics in native North America. University of Alabama Press, Tuscaloosa.

PAUKETAT, T. R. 1997. Specialization, Political Symbols, and the Crafty Elite of Cahokia. Southeastern Archaeology 16:1-15.

PAUKETAT, T. R. 2002. A Fourth Generation Synthesis of Cahokia and Mississippianization. Midcontinental Journal of Archaeology 27:149-170.

PAUKETAT, T. R. 2003. Resettled Farmers and the Making of a Mississippian Polity. American Antiquity 68:39-66

PAUKETAT, T. R. 2004. Ancient Cahokia and the Mississippians. Cambridge University Press.

PAUKETAT, T. R. 2007. Chiefdoms and Other Archaeological Delusions. Alta Mira Press, New York.

PAUKETAT, T. R. 2009. Cahokia: Ancient America's Great City on the Mississippi. Viking-Penguin Press, New York.

PAUKETAT, T. R. 2010. Of Leaders and Legacies in Native North America. In The Evolution of Leadership and Complexity, John Kantner, Kevin J. Vaughn, and Jelmer Eerkins eds., pp. 169-192. School for Advanced Research, Santa Fe, New Mexico.

PAUKETAT, T. R. 2013. An Archaeology of the Cosmos: Rethinking Agency and Religion in Ancient America. Routledge, London.

PAUKETAT, T. R. and EMERSON, T. E. 1991. The Ideology of Authority and the Power of the Pot. American Anthropologist 93(4): 919941.

PAUKETAT, T. R. and EMERSON, T. E. 1997. Cahokia: 
Domination and Ideology in the Mississippian World. University of Nebraska Press, Lincoln.

PAUKETAT, T. R. and Alt, S. M. 2005. Agency in a Postmold? Physicality and the Archaeology of Culture Making. Journal of Archaeological Method and Theory 12:213-237.

PAUKETAT, T. R. and Alt, S. M. 2015. Medieval Mississippians. The Cahokian World. Santa Fe, NM. School for Advanced Research Press.

PERINO, G. 1971. The Mississippian Component at the Schild Site (No. 4), Greene County, Illinois. Mississippian Archaeology in Illinois I: Site Reports from the St. Louis and Chicago Areas. Illinois Archaeological Survey Bulletin 8:1-148

RICHARDS, J. D. 1992. Ceramics and Culture at Aztalan, A Late Prehistoric Village in Southeast Wisconsin. PhD dissertation, Department of Anthropology, University of Wisconsin-Milwaukee, Milwaukee.

SILLIMAN, S. W. 2005. Culture Contact or Colonialism? Challenges in the Archaeology of Native North America. American Antiquity 70:55-74.

STEIN, G. J. 2002. From Passive Periphery to Active Agents: Emerging Perspectives in the Archaeology of Interregional Interaction. Archaeology Division Distinguished Lecture AAA Annual Meeting, Philadelphia, December 5, 1998. American Antiquity 104:903-916.

STOLTMAN, J. B. 1991. Ceramic Petrography as a Technique for Documenting Cultural Interaction: An Example from the Upper Mississippi Valley. American Antiquity 56:103-120

VALESE, I., 2017. The Archaeology of Cahokia's West Plaza. Excavations in the Merrell Tract, Unpublished Ph. D thesis, University of Bologna.
WILSON, G. D. 1996. Insight Through Icons. Illinois Archaeology 8:23-37

WILSON, G. D. 2011. Post-Cahokian Contact in the Central Illinois River Valley. Paper presented at the 76th Annual Meeting of the Society for American Archaeology, Sacramento, California.

WILSON, G. D. and VAN DERWARKER A. M. 2015. The Functional Dimensions of Earth Oven Cooking: An Analysis of an Accidently Burned Maize Roast at the C. W. Cooper Site in West-Central Illinois. Journal of Field Archaeology 40:165-174.

WILSON, G. D., DELANEY C. M. and MILLHOUSE P. G. 2017. The Mississippian of the Illinois and Apple River Valleys. In Mississippian Beginnings, Gregory D. Wilson ed., pp. 97-129. University Press of Florida, Gainesville.

WITTRY, W. and VOGEL, J. 1962. Illinois State Museum Projects: October 1961 to June 1962. In First Annual Report: American Bottoms Archaeology, July 1, 1961-June 30, 1962, M. L. Fowler, ed. Pp. 15-30. Illinois Archaeological Survey, University of Illinois, Urbana.

YOUNG, B. W. and FOWLER, M. L. 2000. Cahokia, the Great Native American Metropolis. University of Illinois Press.

ZYCH, T. J. 2013. The Construction of a Mound and a New Community: An Analysis of the Ceramic and Feature Assemblages from the Northeast Mound at the Aztalan Site. Master's thesis, Department of Anthropology, University of Wisconsin-Milwaukee, Milwaukee. 